\title{
The subfamily Platycnemidinae (Zygoptera: Platycnemididae) in Thailand, with description of the final stadium larva of Copera chantaburii Asahina, 1984
}

\author{
Tosaphol Saetung (iD) ${ }^{\mathrm{a}}$, Noppadon Makbun (iD) ${ }^{\mathrm{b}}$, Michel Sartori (iD) ${ }^{\mathrm{c}, \mathrm{d}}$ and \\ Boonsatien Boonsoong (iD ${ }^{\text {** }}$ \\ ${ }^{a}$ Animal Systematics and Ecology Speciality Research Unit (ASESRU), Department of Zoology, Faculty of \\ Science, Kasetsart University, Bangkok, Thailand; ${ }^{2}$ 211/5 Moo 4, Takhli, Nakhon Sawan, Thailand; \\ ${ }^{c}$ Museum of Zoology, Palais de Rumine, Lausanne, Switzerland; ${ }^{d}$ Department of Ecology and Evolution, \\ Lausanne University, Lausanne, Switzerland
}

(Received 20 January 2020; final version received 3 April 2020)

\begin{abstract}
Within the damselfly subfamily Platycnemidinae, eight species are currently recognized in South-East Asia. The final stadium larvae of only three of them have been so far described. The final stadium larva of Copera chantaburii is described and illustrated for the first time, based on reared specimens, and new provincial records both of larvae and adults of $C$. chantaburii are also provided. The larva of $C$. chantaburii can be distinguished from known species by the following combination of characters: square or almost horizontal rectangular shape of the outer lobe of the labial palp and fimbriated caudal lamellae that are stout at the base and narrow to an acute tip. The final stadium larva of Pseudocopera ciliata is redescribed with possibly diagnostic characters, such as the shape of the distal margin of the labial palp, the ratio of the length of caudal lamellae length and body length, setae on the margin of caudal lamellae and the setae on the terminal filament of the caudal lamellae.
\end{abstract}

Keywords: Odonata; damselfly; Copera; Pseudocopera; larval description; Thailand; dragonfly

\section{Introduction}

The subfamily Platycnemidinae Yakobson \& Bianchi, 1905 represents a group of white-legged damselflies (Platycnemididae) that generally inhabit both lentic and lotic habitats around the Old World (Dijkstra \& Clausnitzer, 2014; Orr, 2005). Six genera are recognized, in two tribes: the Coperini (Copera, Proplatycnemis and Spesbona) and the Platycnemidini (Matticnemis, Platycnemis and Pseudocopera) (Dijkstra, Kalkman, Dow, Stoks, \& Van Tol, 2014; Schorr \& Paulson, 2019). Three species of Copera (C. chantaburii Asahina, 1984, C. marginipes (Rambur, 1842) and $C$. vittata (Sélys, 1863)) and one species of Pseudocopera (P. ciliata (Sélys, 1863)) have been recorded from Thailand (Asahina, 1993). The larval stage of $C$. marginipes and $C$. vittata were described by Lieftinck (1940) and Kumar (1973), whereas no descriptions or illustrations of the larva of $C$. chantaburii have yet been published. Matsuki (1993) provided short description of Pseudocopera ciliata, based on reared specimens from Taiwan and Hong Kong.

*Corresponding author. Email: fscibtb@ku.ac.th 
In the present paper, we provide detailed descriptions of the final stadium larva of $C$. chantaburii for the first time, and redescribe the larva P. ciliata.

\section{Materials and methods}

Last stadium larvae were found in lentic and lotic habitats such as swamp ponds, streams and rivers. The larvae were collected by a D-frame net. This net was suitable to sample the different microhabitats, including the leaf litter, tree roots and submerged vegetation. The last stadium larvae were transferred to the laboratory for rearing until emergence of the adults. The exuviae were also collected around their habitat. The adults were preserved in acetone and dried. The identification was performed based on caudal appendages, following Asahina (1993). The measurements $(\mathrm{mm})$ and photographs were taken using a Nikon SMZ800 (Nikon Instruments Inc., Melville, [New York], USA) a Canon Visionary LK System (Dun, Inc., Palmyra, [Virginia], USA) and a Leica M205C (Leica Microsystems, Heerbrugg, Switzerland). Drawings were made on an iPad using the Procreate application (Savage Interactive Pty. Ltd., North Hobart, [Tasmania], Australia) and based on a representative digital photograph. Final plates were prepared using Adobe Photoshop CC 2017 (Adobe Inc., San Jose, [California], USA). The description of the formula of the larval mandibular formula, the caudal lamellae and the setae on the labium followed the terminology used in Watson (1956), MacNeill (1960) and Kumar (1973), respectively. Abdominal segments 1-10 and antennomeres 1-7 were indicated as S1-S10 and A1-A7, respectively. The specimens are deposited in the Aquatic Insects Collection (AIC) of the Zoological Museum, Kasetsart University (ZMKU), Bangkok, Thailand. Geographic distributions were plotted using SimpleMappr (Shorthouse, 2019).

\section{Results}

Copera Kirby, 1890

Copera chantaburii Asahina, 1984

(Figures 1, 3a, c, 4a, c, e, g-j, 5a, c, e, 6a, c, e, g, 7a, b, Appendices 3, 4a, b, 6a)

Copera chantaburii Asahina, 1984a: 7-9.

Specimens examined. THAILAND: 1 exuvia; (107, emerged) 9 January 2018, Mae Ka Sa Pond (7.57528 N, 99.78667 E, altitude $229 \mathrm{~m})$, Tak province, T. Saetung leg.: 4 F-0 larvae; $\left(20^{7}, 2\right.$ \% $)$ 22 May 2017, Takhli (14.27444 N, 101.04861 E, altitude $22 \mathrm{~m}$ ), Nakhon Sawan province, N. Makbun leg.

Distribution. Thailand and Vietnam.

Addition provincial records. Copera chantaburii has been recorded from eight provinces (Petchaburi, Prachin Buri, Chiang Mai, Nakhon Ratchasima, Ubon Ratchathani, Tak, Samut Prakan and Udon Thani) by photographic records (see Appendix 1)

Description of male larva. Larva small, body short and slender (Appendix 1, Figure 1).

Head. Broad and robust in dorsal view, roughly squashed pentagon in outline; labrum with sparse setae on distal half and basal half glabrous, apical median emargination; frons and vertex irregular knotted, with three prominently ocelli; compound eyes narrow and rounded protruding to lateral side, furnished with numerous spiniform setae; occiput smooth convex shape, anterior margin with large protuberance at corner of compound eyes (Figure 3a, c); postocular lobes well 


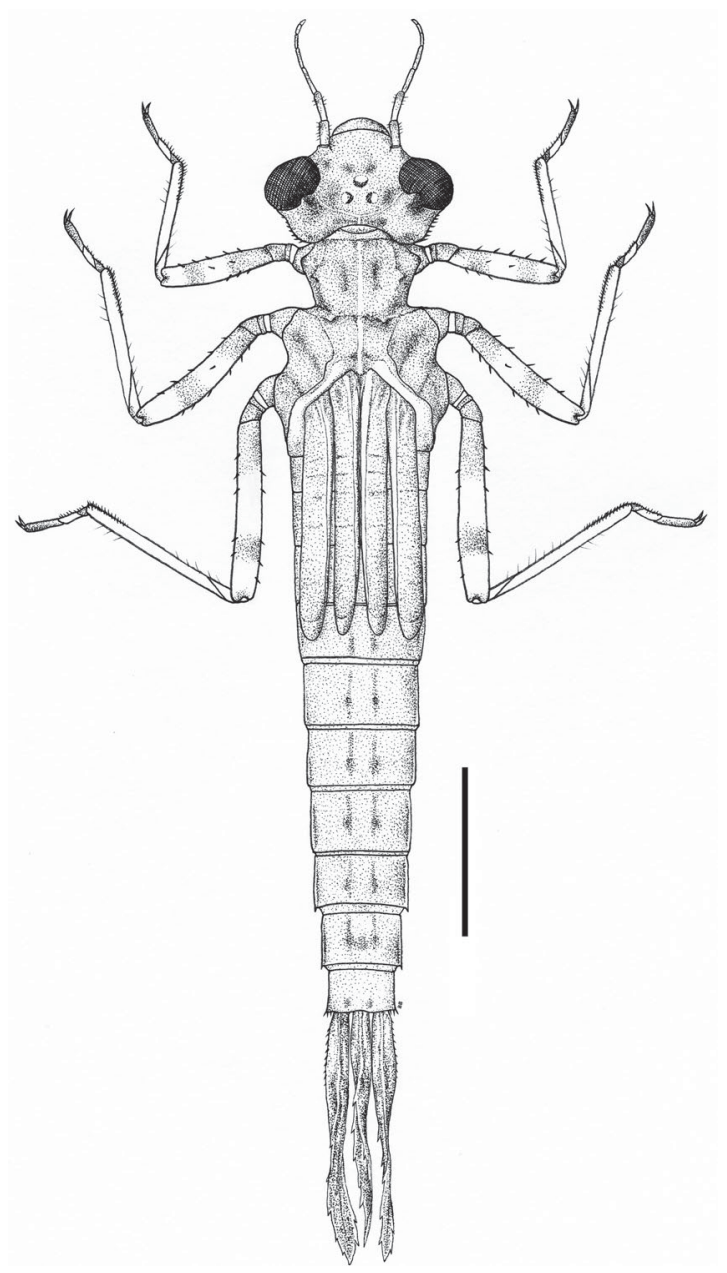

Figure 1. Drawing of Copera chantaburii, larval habitus, dorsal view. Scale $=2 \mathrm{~mm}$.

developed, smoothed on anterior margin, with numerous spiniform setae on posterior margin; genae (Figure 4c) with row of 10 blunted stout spines and simple setae on anterolateral margin, with middle larger than other ones in left gena, with row of six blunted stout spines, larger than other ones in right gena; antennae (Figure 4a) filiform, 7-segmented, with A2 and A3 the longest, with an apical spine on A6, relative length of antennomeres 0.85: 1 (0.64 mm): 0.99: 0.78: 0.51: 0.42: 0.24; prementum (Figure 5a) subpentagonal shape extending posteriorly up to the middle of the fore coxae, with two pair premental setae, with a row of 19-23 spiniform setae along lateral margin of each side, laterodistal margin with 3 minute and 3 distinct spiniform setae and with two long setae on middle of ventral side (Figure 5c); ligula strongly produced to form an obtuse angle, the two slightly convex sides forming an angle of about $130^{\circ}$, with one pair protuberances and 48 minute spiniform setae along margin; labial palp (Figure 5e) as long as $0.34 \times$ of prementum, with $4+4$ palpal setae, outer margin with serrate spiniform setae, distal margin divided into 2 lobes, the outer lobe forming square, truncate, denticulate lobe with 4 distinct teeth, inner lobe forming end hook blunt pointed, and movable hook slender about $0.79 \times$ as long as labial palp, acuminate, bent inwards; maxilla (Figure 4e) galeolacinia with 6 teeth, four dorsal teeth of approximately the same size, apical teeth largest, two ventral teeth of small size. 


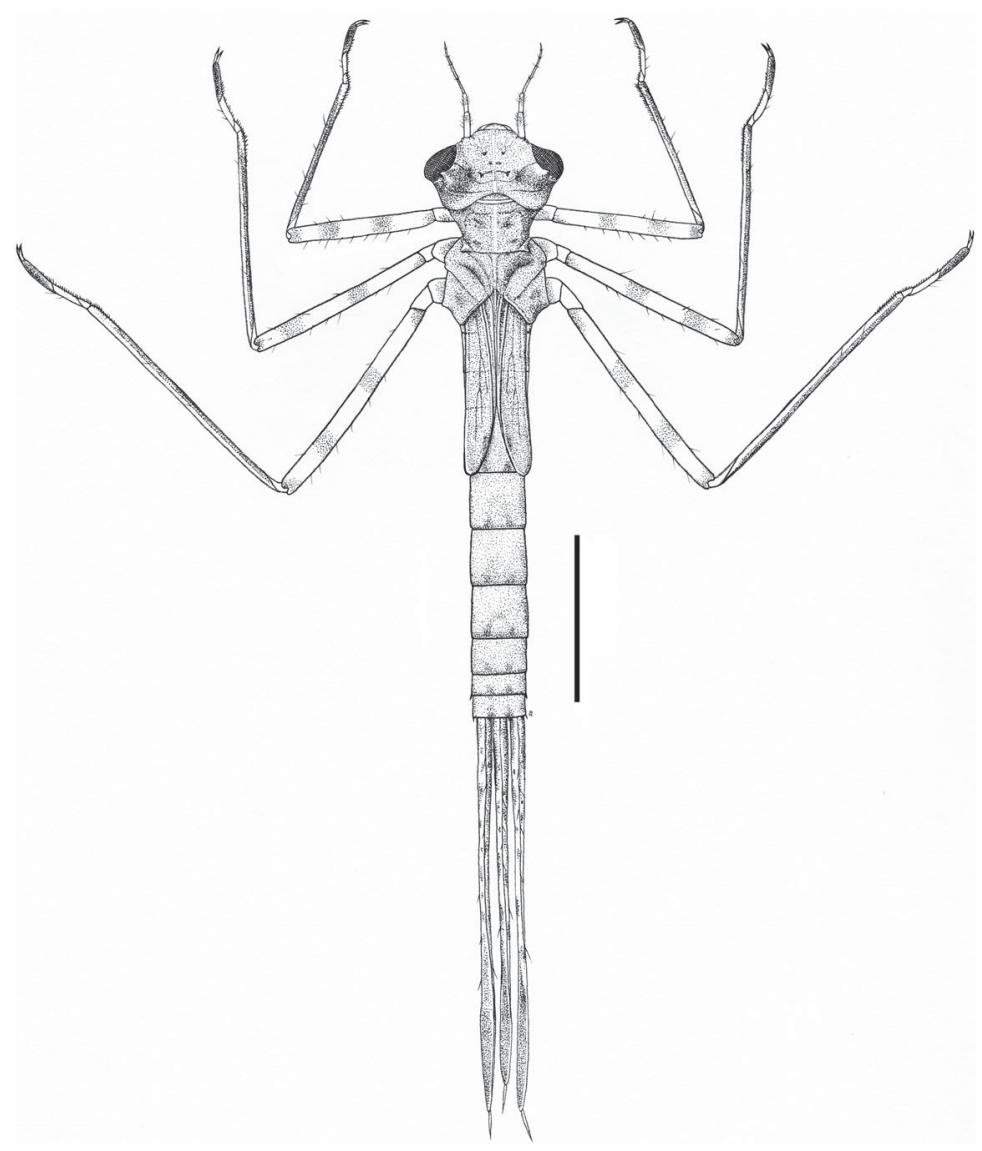

Figure 2. Drawing of Pseudocopera ciliata, larval habitus, dorsal view. Scale $=2 \mathrm{~mm}$.

Mandible (Figure 4g-j) with well-developed long teeth on each incisor lobe, without molar crest; left mandible with five incisor teeth, two molar teeth $(\mathrm{a}>\mathrm{b})$; right mandible with five incisor teeth, one molar tooth, an additional tooth and following mandibular formula: L $1+1$ '234 a b/ $\mathrm{R} 1+1 ’ 234$ y a.

Thorax. Narrower than head, with scattered setae, with almost hexagonal shape, anterior margin reaches to concave of postocular lobe, posterior margin forming rounded slightly keeled; prothoracic process blunted, smooth; angulated pronotum disc; synthorax with scattered setae and minute protuberance; wing pads pale with glabrous, parallel, anterior and posterior wing pads reaching to distal margin of abdominal segment 4; legs almost flat and long; femora thin with dark band on posterior side, row of spiniform setae and scattered setae; hind femora as long as $1.57 \times$ and $1.35 \times$ length of fore and mid femora, respectively; tibiae combed, with scattered setae and a few tridentate setae; tarsi formula: $3-3-3$; two claws simple with pulvilliform empodium.

Abdomen. Cylindrical shape, slender, narrowing caudally, with scattered setae; abdominal terga with two longitudinal pale black stripes on midline, with a couple of black spots on middle between mid-line; abdominal sterna with a pale network of tracheoles, with dark spots on posterolateral side; abdominal pleura with row of setae, abdominal pleura S1-S7 flattened, with dark triangular spot, abdominal pleura S8-S10 with distinct spiniform setae on posterolateral end, abdominal S10 with cluster of spiniform setae externally at the basal of cerci; male 

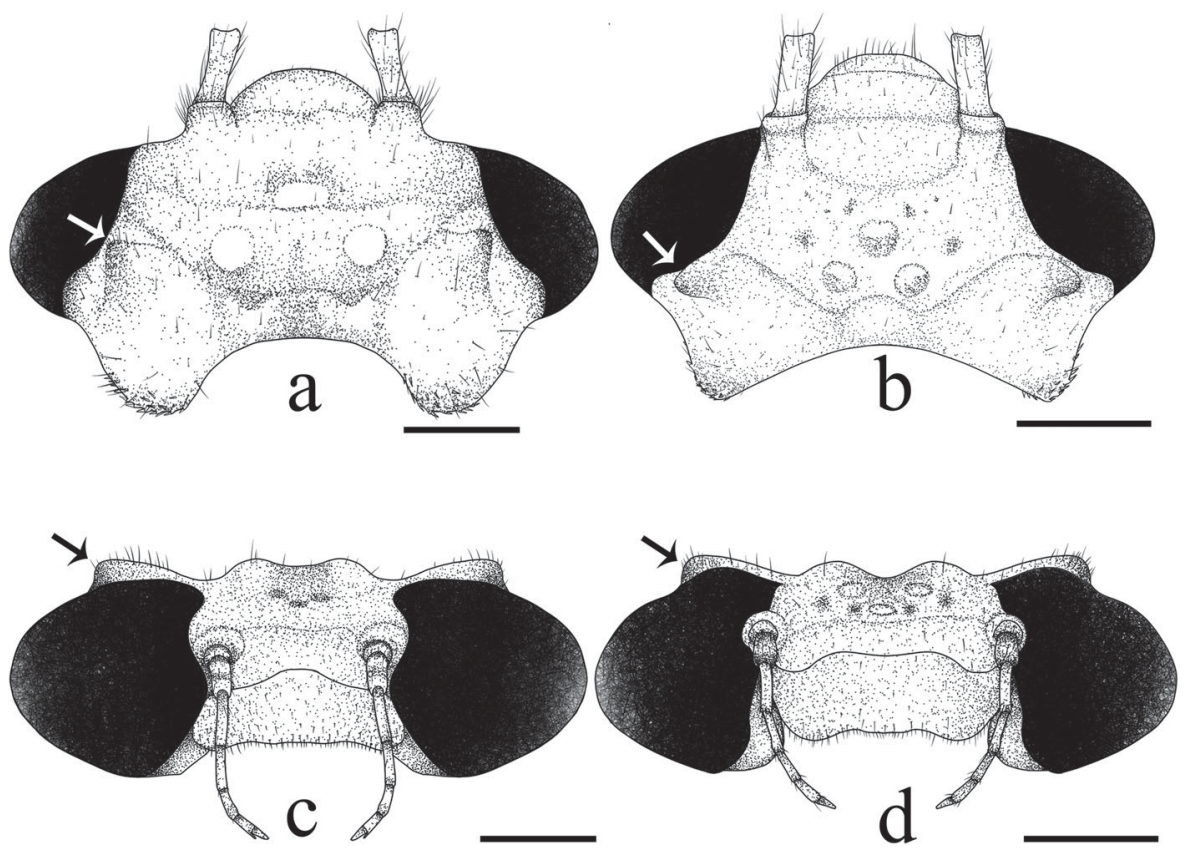

Figure 3. Head of Copera chantaburii (a, c) and Pseudocopera ciliata (b, d); (a, b) dorsal view; (c, d) frontal view (arrow $=$ protuberance on occiput margin). Scale $=1 \mathrm{~mm}$.

gonapophyses (Figure 6a, c) base stout, sharply pointed, widely divergent in ventral view, reaching anterior margin of sternite S10, with a row of setae on ventral margin; gonopore very small, O-shape embossed and fissure on middle to posterior (Figure 6c); caudal lamellae (Figure 7a, b) forming the duplex gills, anterior region with yellowish smudged marking forming acutangular shape, posterior region scattered pale white spots, widely on its distal end of median trachea, strongly stout, short fimbriated on margin, median gill shorter than lateral gills; tracheation well developed, a median trachea largest, indistinct, reaching 4/5 of caudal lamellae; secondary branches, irregularly branched, little undulate extended to distal margin and small tertiary branches arise to margin side; median gill anterior portion with 5 spiniform setae on dorsal margin and sparsely 9 spiniform setae on ventral margin, median trachea with 4 spiniform setae scattered; lateral gills anterior portion with 18 spiniform setae on dorsal margin and sparsely 9 spiniform setae on ventral margin, median trachea with 7 spiniform setae array on outer side and scattered.

Description of female larva. As male, unless otherwise stated: female gonapophyses (Figure 6e, g) comprising two pairs of long valvae; lateral valvae with sharply pointed processes, slightly divergent, with a row of setae and distinct single spiniform setae on each side, reaching over sternite 10; central valvae shorter than as lateral valvae, slender, apically rounded.

Larval morphological variation. Coloration varied, yellowish cream to brownish black. Articulation of labium extended at level of middle coxae of foreleg up to anterior coxae of midleg. Genae with 7-11 rows of blunted stout spines. Prementum with row of 15-22 spiniform setae along distal half of lateral margins, laterodistal margin with 2-4 spiniform setae. Some specimens without apical spine on A6. Distal part of incisor teeth showed a consistent shape among all examined specimens. Anterior and posterior wing pads reaching half of S3 to almost S5. Caudal lamellae with irregular fimbriated margin and tip of each fimbriated forming pointed or blunted; 


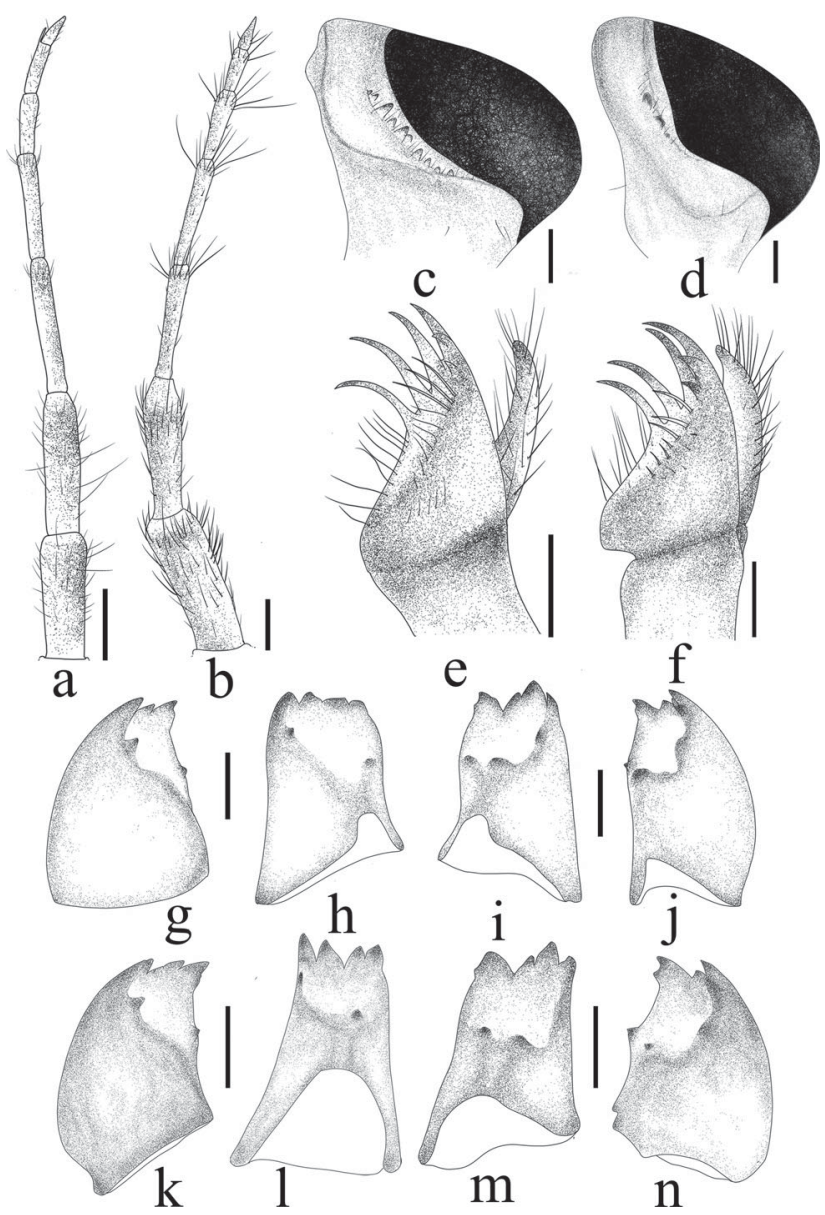

Figure 4. Detail of morphology of Copera chantaburii (a, c, e, g-j) and Pseudocopera ciliata (b, d, f, k-n); (a, b) right antenna, dorsal view; (c, d) left gena; (e, f) left galeolacinia, dorsal view. (g, k) right mandible, ventral view; $(\mathrm{h}, \mathrm{l})$ right mandible, ventrointernal view; (i, m) left mandible, ventrointernal view; $(\mathrm{j}, \mathrm{n})$ left mandible, ventral view. Scale $=0.2 \mathrm{~mm}$.

antenodal region of median gill with 11-15 spiniform setae on dorsal margin and sparsely 26 spiniform setae on ventral margin, median trachea with 3-6 spiniform setae array on both sides. Antenodal region of lateral gills with 6-9 spiniform setae on dorsal margin and 9-18 spiniform setae on ventral margin, median trachea with 6-11 spiniform setae array on outer sides.

Diagnosis. The larva of Copera chantaburii is closely similar to those of $C$. marginipes, but it can be distinguished by (1) almost horizontal rectangular shape of outer lobe of labial palp and (2) fimbriated caudal lamellae, stout basally and narrowing to acute tip (Appendix 4a, b).

Measurements See in Appendix 2.

Biological notes. The larvae of Copera chantaburii inhabit lentic waters, such as a small seasonal pond. It often hides in an accumulation of leaves under the water (Appendix 5b, d). Basically, they display agonistic behaviour as a tendency to keep the distal margin end of the abdomen somewhat upturned, while the caudal lamellae remain gently free and pointing headward (Appendix 6a). 

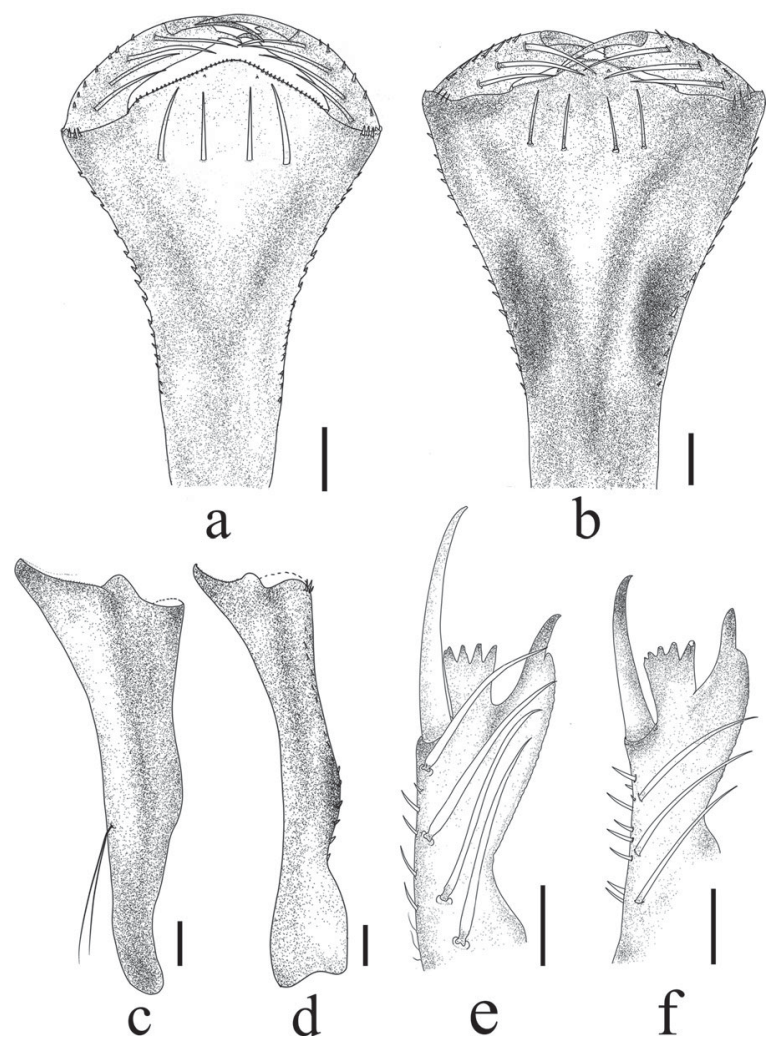

b

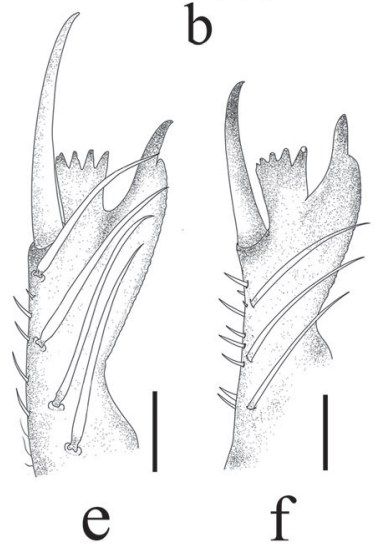

Figure 5. Labium of Copera chantaburii (a, c, e) and Pseudocopera ciliata (b, d, f); (a, b) prementum, dorsal view; (c, d) prementum, lateral view; (e, f) labial palp, dorsal view. Scale $=0.2 \mathrm{~mm}$.

\section{Pseudocopera Fraser, 1922}

\section{Pseudocopera ciliata (Sélys, 1863)}

(Figures 2, 3b, d, 4b, d, f, k-n, 5b, d, f, 6b, d, f, h, 7c, d, Appendix 6d)

Psilocnemis ciliata Sélys, 1863: 25.

Pseudocopera trotteri Fraser, 1922: 237-238.

Copera ciliata Asahina, 1984a: 9; Asahina, 1984b: 2-10; Musuki, 1993: 22-24. Orr, 2005: 49

Pseudocopera ciliata Dijkstra et al., 2014: 93.

Specimens examined. THAILAND: 2 exuviae; (10 $10^{7}$, emerged) 18 May 2017, Wang Nam Rab resort $(7.57528$ N, $99.78667 \mathrm{E}$, altitude $144 \mathrm{~m})$, Trang province, T. Saetung leg.: 2 F-0 larvae; $\left(10^{7}, 1\right.$ ) $) 18$ October 2017, Ban Na (14.27444 N, 101.04861 E, altitude 10 m), Nakhon Nayok Province, T. Saetung leg.

Distribution. Southeast Asia

Redescription of male larva. Larvae slender, body very long (Figure 2).

Head. Broad and robust in dorsal view, roughly squashed pentagon in outline, with scattered setae and white spot; labrum with sparse setae on distal half and basal half glabrous, apical median emargination; frons and vertex irregular knotted, with three prominent ocelli; compound eyes narrow and rounded protruding lateral side; occiput smooth convex shape, anterior margin 


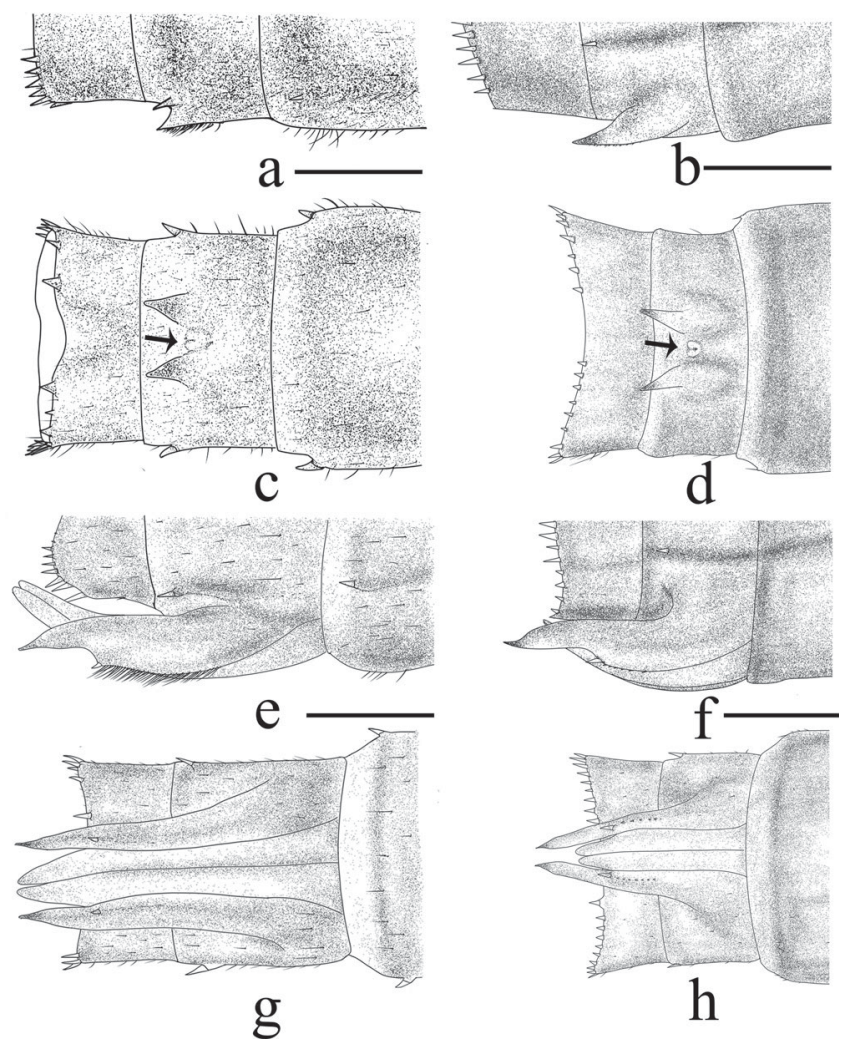

Figure 6. Detail of S8-S10 (caudal lamellae detached) of Copera chantaburii (a, c, e, g) and Pseudocopera ciliata (b, d, f, h); (a, b) male gonapophyses, lateral view; (c, d) male gonapophyses, ventral view (arrow = gonopore); (e, f) female gonapophyses, lateral view; $(\mathrm{g}, \mathrm{h})$ female gonapophyses, ventral view. Scale $=0.5 \mathrm{~mm}$.

with large protuberance at corner of compound eyes (Figure 3b, d); postocular lobes well developed, rounded, smoothed on anterior margin, with numerous spiniform setae on posterior margin; genae (Figure 4d) large, with row of three blunted stout spines and simple setae on anterolateral margin, with middle larger than other ones in left gena, and row of two blunted stout spines, middle larger than other ones in right gena; antennae (Figure 4b) filiform, 7-segmented with A3 and A4 the longest, relative length of antennomeres 0.59: 0.58: 1 (0.64 mm): 0.89: 0.39: 0.21: 0.14; prementum (Figure $5 \mathrm{~b}$ ) subpentagonal shape extending posteriorly up to the middle of the fore coxae, with dark band on middle part, having two pairs of premental setae, laterodistal margin and 3 distinct spiniform setae, with a row of 16-18 spiniform setae along distal half of lateral margin; ligula strongly produced to form an obtuse angle, the two slightly convex sides; with one pair protuberances and a minute spiniform setae along margin; without setae on middle of ventral side (Figure 5d); labial palp (Figure 5f) as long as $1 / 2$ of prementum with $3+3$ palpal setae, outer margin with serrate spiniform setae, distal margin divided into 2 lobes, the outer lobe square, truncate, denticulate with 5 distinct teeth and inner lobe bears end hook with blunt tip; movable hook slender and about 0.71 times as long as labial palp, acuminate, bent inwards; maxilla (Figure 4f) galeolacinia with 6 teeth, four dorsal teeth approximately of the same size, apical teeth largest, two ventral teeth of small size. Mandible (Figure 4k-n) with well-developed long teeth on each incisor lobe, without molar crest; left mandible with five incisor teeth, two molar teeth $(\mathrm{a}=\mathrm{b})$; right mandible with five incisor teeth, one molar tooth, an additional tooth and following mandibular formula: L $1+1$ '234 a b/ R 1 + 1'234 y a. 


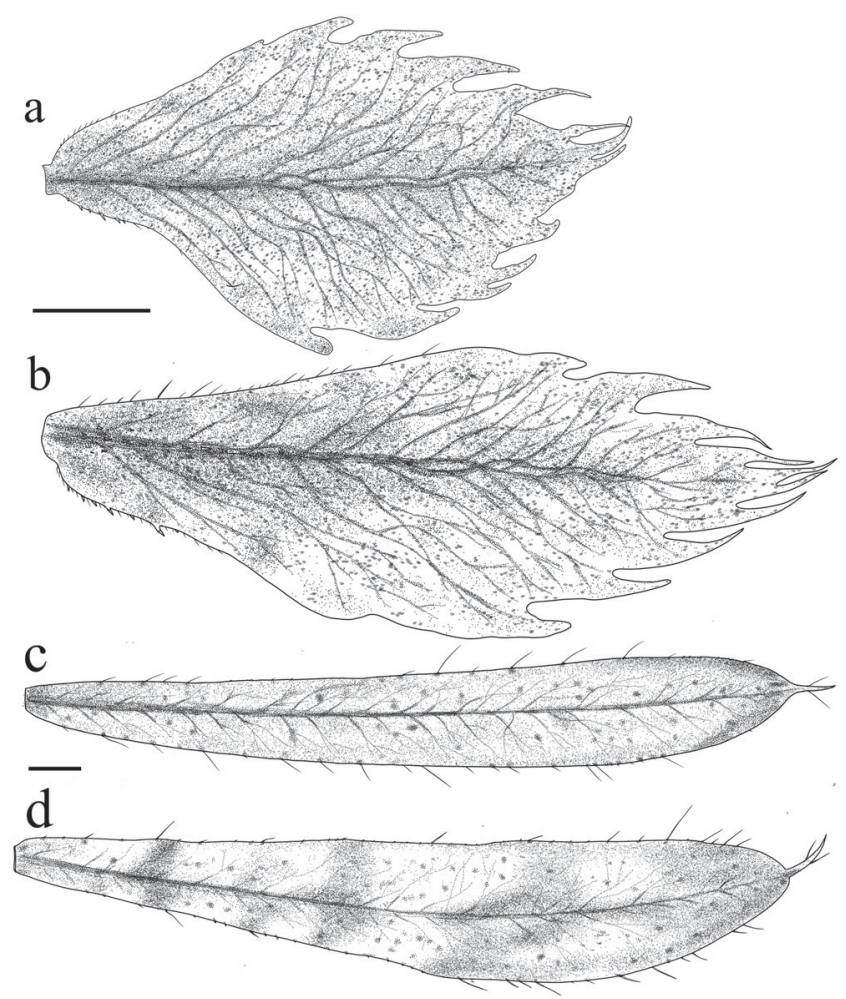

Figure 7. Caudal lamellae of Copera chantaburii (a, b) and Pseudocopera ciliata (c, d); (a, c) median gill; (b, d) lateral gill. Scale $=0.5 \mathrm{~mm}$.

Thorax. Narrower than head, with scattered setae and white spot, with almost hexagonal shape, scattered setae and minute protuberance, anterior margin reach to concave of postocular lobe, middle lobe with pale yellow line on mid line; prothoracic process blunted, angulated; pronotum disc smooth, rounded, slightly keeled; synthorax scattered setae and minute protuberance; wing pads pale with glabrous, parallel, anterior and posterior wing pads reaching to distal margin of abdominal segment 4; legs almost flat and long; femora thin with dark band on posterior side, row of spiniform setae and scattered unidentate setae; hind femora as long as $1.83 \times$ and $1.34 \times$ length of fore and mid femora, respectively; tibia comb with scattered setae and a few tridentate setae; tarsi formula: 3-3-3; two claws simple with pulvilliform empodium.

Abdomen. Cylindrical shape, slender, narrowing caudally, scattered setae, minute protuberance and white spot; abdominal terga with longitudinal pale black line, posterior margin with a couple of pale black spots on middle; abdominal sterna with a pale network of tracheoles, with scattered setae, with pale dark spots on posterolateral side; abdominal pleura flatted on S1-S9 and distinct spiniform setae on posterolateral end of S9-S10, S10 with cluster of spiniform setae externally at the basal of cerci; male gonapophyses (Figure 6b, d) sharply pointed, widely divergent in ventral view, reaching anterior margin of sternite 10, with a row of setae on ventral margin; gonopore very small, O-shape embossed and fissure on middle to posterior (Figure 6d); caudal lamellae (Figure 7c, d) forming simplex-denodated gills large, long and broad, with irregular light and shade markings, several irregular tiny and long setae along margin, with long terminal filament on apex of lamellae and its one pair of setae, with a little protuberance. Tracheation unclearly developed, a distinct median trachea, reaching terminal filament; secondary branches, irregularly branched, little undulate extended to distal margin and small tertiary branches arise 


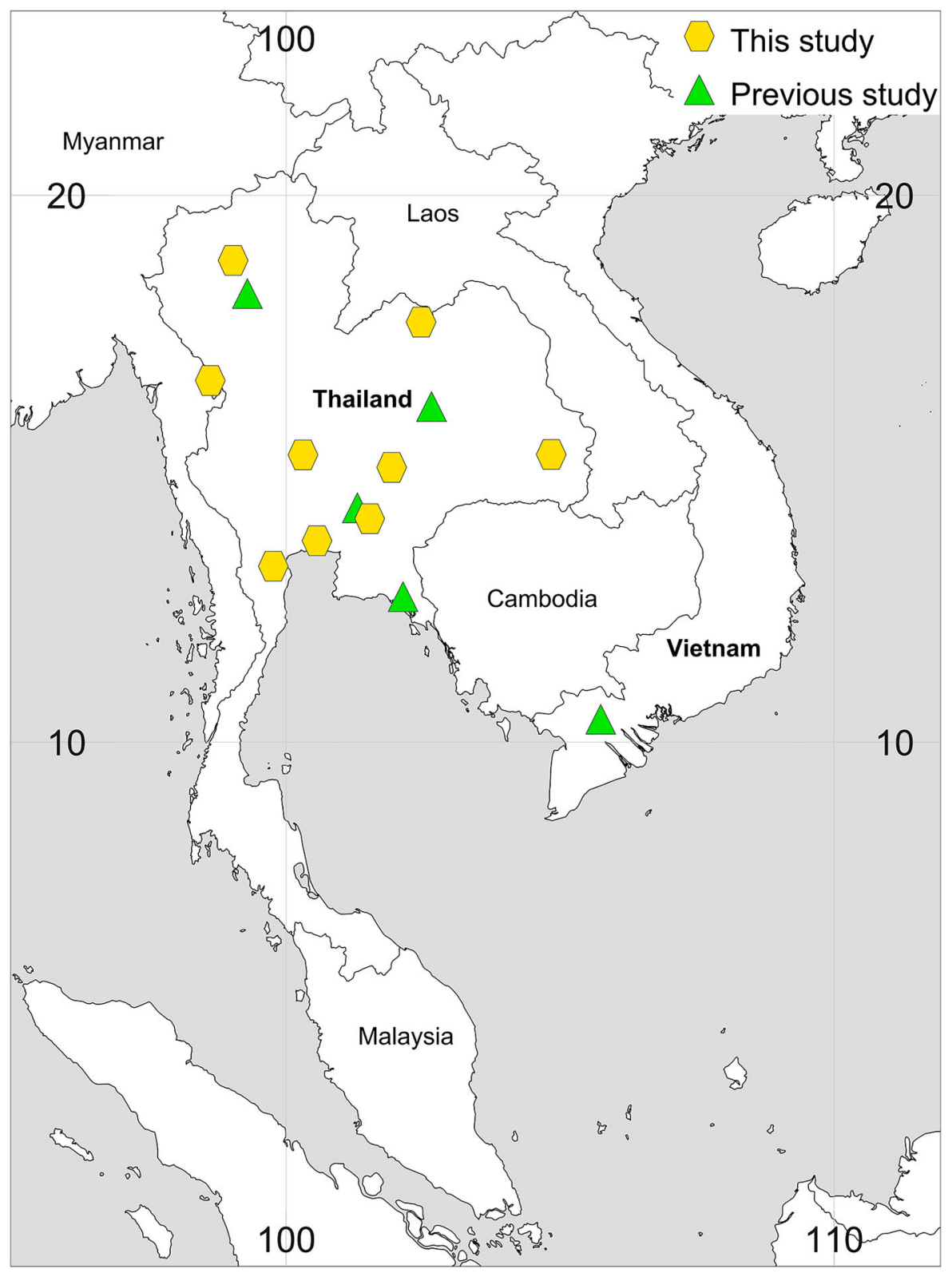

Figure 8. Geographic distribution of Copera chantaburii.

to margin side; median lamella with length longer than $2.09 \times$ its widest width, with 26 and 21 setae on dorsal and ventral margin, respectively, lateral lamellae with length longer than $2.47 \times$ its widest width, with 39 and 32 setae on dorsal and ventral margin, respectively.

Redescription of female larva. As male, unless otherwise stated: female gonapophyses (Figure 6f, h) comprising two pairs of long valvae; lateral valvae with sharply pointed processes, slightly divergent, with a row of setae and distinct one spiniform setae and followed by 7-8 small spiniform setae on each side, extending over sternite 10; central valvae slightly shorter with lateral valvae, slender, apically rounded. 
Larval morphological variation. Coloration varied, yellowish cream to yellowish black. Articulation of prementum and postmentum extended at level of middle coxae of foreleg up to anterior coxae of midleg. Genae with 3-5 rows of blunted stout spine. Prementum with row of 16-20 spiniform setae along distal half of lateral margins, laterodistal margin with 2-3 spiniform setae. Mandibles show a consistent shape among all examined specimens. Anterior and posterior wing pads reaching half of S3 to almost posterior of S4. Caudal lamellae with irregular marking and numerous of setae on margin.

Diagnosis. The larvae of Pseudocopera ciliata can be distinguished from other species by setae on terminal filament on caudal lamellae and length of caudal lamellae approximately $0.95 \times$ body length, square or vertical rectangular shape of labial palp, a few row of setae on the margin of caudal lamellae.

Measurements. See in Appendix 2

Biological notes. The larvae of Pseudocopera ciliata inhabit lentic and lotic water, such as slow flowing streams, lakes and seasonal ponds. They inhabit among submerged vegetation and leaf litter (Appendix 5b, c). They display agonistic behaviour as a tendency to keep the distal margin end of the abdomen somewhat upturned, while the caudal lamellae remain gently free and pointing headward (Appendix 6d).

\section{Copera marginipes (Rambur, 1842)}

(Appendix 4c, d, 6b)

Platycnemis marginipes Rambur, 1842: 240-241; Needham, 1930: 250-251.

Psilocnemis marginipes Sélys, 1863: 168.

Platycnemis lacteola Sélys, 1863: 167; Kirby, 1890:129.

Psilocnemis striatipes Sélys, 1863: 169; Kirby, 1890:129.

Disparoneura bhatnagri Sahni, 1965: 209; Hämäläinen, 1987: 17.

Copera marginipes Kirby, 1890: 129; Fraser, 1919: 464-465; Fraser, 1933: 192-197; Lieftinck, 1940: 282-306; Kumar, 1973: 86-87; Asahina, 1984a: 6-7; Fonseka, 2000: 53-54, 231; Orr, 2005: 49.

Specimens examined. THAILAND: 2 exuviae; (10, emerged) 14 March 2015, Kang Som Meaw (13.40778 N, 99.28111 E, altitude $200 \mathrm{~m}$ ), Ratchaburi province, T. Saetung leg.; (1o, emerged) 22 March 2015, Nang Rong Waterfall (14.31389 N, 101.30667 E, altitude 37 m), Nakhon Nayok province, T. Saetung leg.: 2 F-0 larvae; (10 $) 25$ February 2018, Huai Sat Lek, (12.63575 N, 99.51139 E, altitude $181 \mathrm{~m}$ ), Phetchaburi, T. Saetung leg.; (1\%) 21 April 2018, Klong Aika Ding, (5.79583 N, 101.83472 E, altitude 56 m), Narathiwat Province, T. Saetung leg.

Distribution. Oriental region

Diagnosis. The larva of Copera marginipes is closely similar to those of C. vittata and $C$. chantaburii but it can be distinguished by (1) vertical rectangular shape of outer lobe of labial palp and (2) fimbriated caudal lamellae that are almost stout basally and narrowing to slender at middle to acute tip (Appendix 4c, d).

Copera vittata (Sélys, 1863)

(Appendix 4e, f, 6c)

Psilocnemis vittata Sélys, 1863: 170. 
Table 1. Comparison of larval characteristics and habitats both of Copera spp. and Pseudocopera ciliata.

\begin{tabular}{|c|c|c|c|c|}
\hline & C. vittata & C. marginipes & C. chantaburii & P. ciliata \\
\hline $\begin{array}{l}\text { Palpal setae } \\
\text { (Figure 5f, g) }\end{array}$ & $4+4$ & $4+4$ & $4+4$ & $3+3$ \\
\hline $\begin{array}{l}\text { Spines on gena } \\
\text { (Figure } 4 c, d \text { ) }\end{array}$ & $8-10$ & $8-12$ & $7-11$ & $3-5$ \\
\hline $\begin{array}{l}\text { Type of caudal gills } \\
\text { (Figure } 7 \text { ) }\end{array}$ & Duplex- nodated gills & Duplex- nodated gills & Duplex- nodated gills & $\begin{array}{l}\text { Simplex-denodated } \\
\text { gills }\end{array}$ \\
\hline $\begin{array}{l}\text { The shape of the } \\
\text { fimbriated caudal } \\
\text { lamellae (Figure 7) }\end{array}$ & Slender basally & Stout basally & Stout basally & $\begin{array}{l}\text { Without fimbriated } \\
\text { caudal lamellae }\end{array}$ \\
\hline $\begin{array}{l}\text { The shape of distal } \\
\text { margin end of the } \\
\text { labial palp } \\
\text { (Figure 5f, g) }\end{array}$ & $\begin{array}{l}\text { Square or vertical } \\
\text { rectangular shape }\end{array}$ & $\begin{array}{c}\text { Horizontal rectangular } \\
\text { shape }\end{array}$ & $\begin{array}{l}\text { Square or vertical } \\
\text { rectangular shape }\end{array}$ & $\begin{array}{l}\text { Square or vertical } \\
\text { rectangular shape }\end{array}$ \\
\hline Habitats (Appendix 5) & $\begin{array}{c}\text { Lotic water } \\
\text { (headwater stream or } \\
\text { forest stream) }\end{array}$ & $\begin{array}{c}\text { Lotic (stream, river) } \\
\text { and lentic water } \\
\text { (pond near stream or } \\
\text { river) }\end{array}$ & $\begin{array}{l}\text { Lentic water (seasonal, } \\
\text { permanent pond) }\end{array}$ & $\begin{array}{c}\text { Lentic (lake, pond) and } \\
\text { lotic water (slow- } \\
\text { running stream) }\end{array}$ \\
\hline $\begin{array}{l}\text { Microhabitats } \\
\text { (Appendix 5) }\end{array}$ & $\begin{array}{l}\text { Pool or riffle } \\
\text { (vegetation and } \\
\text { root tree) }\end{array}$ & $\begin{array}{l}\text { Pool or riffle } \\
\text { (vegetation and } \\
\text { root tree) }\end{array}$ & Leaf litter, vegetation & $\begin{array}{l}\text { Pool (vegetation and } \\
\text { root tree) and floating } \\
\text { plant }\end{array}$ \\
\hline
\end{tabular}

Copera vittata vittata Lieftinck, 1940: 282-306.; Asahina, 1984a: 9-12.

Copera vittata Kirby, 1890: 129; Fraser, 1933: 198-201; Orr, 2005: 48-49.

Specimens examined. THAILAND: 1 exuviae; (10 , emerged) 10 November 2018, Klong Om Tala (14.35661 N, 99.13028 E, altitude 520 m), Kanchanaburi Province, T. Saetung leg.: 2 F0 larvae; (107, 1ㅇ) 21 April 2017, Klong Aika Ding (5.79583 N, 101.83472 E, altitude $56 \mathrm{~m}$ ), Narathiwat Province, T. Saetung leg.

Distribution. Oriental region

Diagnosis. The larva of Copera vittata is closely similar to those of $C$. marginipes, but it can be distinguished by (1) vertical rectangular shape of outer lobe of labial palp and (2) fimbriated caudal lamellae slender from base to acute tip (Appendix 4e, f).

\section{Discussion}

Taxonomic larval characters for distinguished subfamily levels of the Platycnemididae are still uncertain because the members have highly consistent characters (Orr \& Dow, 2015). However, the subfamily Platycnemidinae has synapomorphic characters, such as the protuberance at the corner of the compound eyes (Figure 3) and two pairs of premental setae (Figure 5a, b) (Deacon \& Samways, 2016; Lieftinck,1940; Matsuki, 1993). The general morphology of the genus Copera clearly differs from that of the genus Pseudocopera by the shape of the caudal lamellae (Orr \& Dow, 2015) as the adult can be distinguished by genital ligula (Dijkstra, 2013). Pseudocopera ciliata is greatly similar to P. annulata and P. tokyoensis (Chowdhury \& Miah, 1990; Yum \& Bae, 2007). Matsuki (1993) provided distinguishing characters for P. ciliata and P. annulata, which are the ratio of the length and widest width of the caudal lamellae, and the ratio of the terminal tip and widest width of the caudal lamellae. But these characters seem to be 
unreliable, because ratios of these characters are highly variable among individuals of our $P$. ciliata specimens within the range of $P$. annulata. However, the present study identified possibly distinguishing characters for $P$. ciliata, such as the shape of the distal margin of the labial palp (square or vertical rectangular shape in P. ciliata; vertical rectangular shape in $P$. tokyoensis; not mentioned in $P$. annulata), the ratio of the length of caudal lamellae and body length (caudal lamellae length is shorter than $0.8 \times$ body length in $P$. annulata and P. tokyoensis; caudal lamellae length is longer than $0.8 \times$ body length in $P$. ciliata), setae on the margin of caudal lamellae (few in P. annulata and P. ciliata; numerous in P. tokyoensis) and the setae on the terminal filament of the caudal lamellae (one pair setae in P. ciliata; absent in P. annulata and P. tokyoensis) (Chowdhury \& Miah, 1990; Yum \& Bae, 2007).

Among the five Asian species of Copera, two species (C. imbricata and C. rubripes) are poorly known so far, and no description of the larval stage is available (Lieftinck, 1940; Navás, 1934). The current analysis of the morphological characters of three known larvae allows us to summarize the taxonomic characters (Table 1) as follows: the shape of fimbriated caudal lamellae (slender basally in $C$. vittata; stout basally in $C$. chantaburii and $C$. marginipes) and the shape of distal margin of the labial palp (forming square or vertical rectangular shape in $C$. marginipes and $C$. vittata; forming horizontal rectangular shape in $C$. chantaburii). The larvae of the Platycnemidinae flourish in a wide variety of biotopes. Basically, the larvae of $C$. marginipes and $C$. vittata were usually found amidst aquatic vegetation in streams, especially headwater streams (Kumar, 1973; Saetung \& Boonsoong, 2016), whereas the larvae of C. chantaburii favour lentic waters, as does P. ciliata (Chowdhury \& Miah, 1990; Saetung \& Boonsoong, 2019). Both Copera and Pseudocopera have dominant agonistic behaviour as the same display position in each species, which is the characteristic behaviour of platycnemid larva, (Rowe, 1992) (Appendix 6).

Copera chantaburii is only known from Thailand and Vietnam (Phan, 2019). In Thailand, Hämäläinen \& Pinratana (1999), Day et al. (2012) and Phan (2019) recorded it in Chanthaburi, Lampang, Nakhon Nayok and Khon Kean provinces. Recently, further specimens and reliable photographic records have been collected, bringing the number of provinces up to 13 around the upper part of Thailand (Figure 8). Unlike the widespread C. marginipes and C. vittata, an intensive survey of Copera chantaburii is needed in the area between Thailand and Vietnam to fill in the gaps of its distribution, and another region such as Myanmar and southern Thailand.

\section{Acknowledgements}

The ethics statement was approved by the ethics committee of Kasetsart University (approval no. ACKU 61-SCI-031) for rearing and collecting the damselflies. We are most grateful to our Aquatic Insects subunit members for assistance during field trips. We would especially like to thank Dr Jean-Luc Gattolliat, Dr Klaas-Douwe B. Dijkstra, Dr Akihiko Sasamoto and Dr Kaewpawika Rattanachan for giving valuable suggestions and providing the literature necessary for the present study. Noppadon Makbun is grateful to all members of the Facebook group "Dragonflies of Thailand" for providing photographic records of Copera chantaburii: John Sim, Narong Thepphibalsathit, Nattawut Runghirun, Pattarawich Dawwrueng, Pitsamai Thanomji, Reinthong Ruangrong, Sompong Tesring, Tosaporn Thitiarchagul, Wilaiwan Panadit, and Navapol Komanasin. We are grateful to two anonymous reviewers and the editor for critically reading and editing the manuscript.

\section{Funding}

The project was supported in part by Faculty of Science, Kasetsart University, the capacity building of KU students on internationalization program: KUCSI of the international affairs division, Kasetsart University and Centre of Excellence on Biodiversity (BDC) Office of Higher Education Commission (BDC-PG2-161004).

\section{ORCID}

Tosaphol Saetung (D) http://orcid.org/0000-0001-7565-4701 
Noppadon Makbun (iD http://orcid.org/0000-0003-4659-0192

Michel Sartori (D) http://orcid.org/0000-0003-3397-3397

Boonsatien Boonsoong (D) http://orcid.org/0000-0002-8166-0021

\section{References}

Asahina, S. (1984a). A list of the Odonata from Thailand. Part IV. Platycnemididae I (Genus Copera). Chô Chô, 7(12), $5-13$.

Asahina, S. (1984b). "Copera annulata (Sélys)" composed of two different species. Chô Chô, 7, 2-10.

Asahina, S. (1993). A list of the Odonata from Thailand (Parts I-XXI). Bangkok: Bosco Offset.

Chowdhury, S. H., \& Miah, M. I. (1990). Descriptions of four zygopteran larvae from the Chittagong University Campus. Chittagong University studies. Part II: Science, 14(1), 127-136.

Day, L., Farrell, D., Gibert, E., Günther, A., Hämäläinen, M., Klimsa, E., . . Vikhrev, N. (2012). New provincial records of Odonata from Thailand mostly based on photographs. Agrion, 16(1), 16-25.

Deacon, C., \& Samways M. J. (2016). Larva of one of the world's rarest and most threatened damselflies: Spesbona angusta (Odonata: Platycnemididae). Odonatologica, 45(3/4), 225-234. doi:10.5281/zenodo. 163450

Dijkstra, K.-D. B. (2013). Three new genera of damselflies (Odonata: Chlorocyphidae, Platycnemididae). International Journal of Odonatology, 16(3), 269-274. doi:10.1080/13887890.2013.832606

Dijkstra, K.-D. B., \& Clausnitzer, V. (2014). The dragonflies and damselflies of eastern Africa, Handbook for all Odonata from Sudan to Zimbabwe. Tervuren, Belgium: Belgian Royal Museum for Central Africa.

Dijkstra, K.-D. B., Kalkman, V. J., Dow, R. A., Stoks, F. R., \& Van Tol, J. (2014). Redefining the damselfly families: a comprehensive molecular phylogeny of Zygoptera (Odonata). Systematic Entomology, 39(1), 68-96. doi:10.1111/syen. 12035

Fonseka, T. (2000). The dragonflies of Sri Lanka. Colombo: WHT Publications.

Fraser, F. C. (1919). Descriptions of new Odonate larvae and exuviae. Records of the Indian Museum, 16, 459-467.

Fraser, F. C. (1922). A collection of dragonflies from Bangkok. The Journal of the Natural History Society of Siam, 4 , 231-238.

Fraser, F. C. (1933). The fauna of British India - Odonata. London: Taylor and Francis.

Hämäläinen, M. (1987). Odonata from the Dehra Dun Valley (Uttar Pradesh, India) with notes on synonymy of some West Himalayan species. Odonatologica, 18(1), 13-20.

Hämäläinen, M., \& Pinratana, A. (1999). Atlas of the Dragonflies of Thailand. Distribution maps by provinces. Bangkok: Chok Chai Creation Printing Group.

Kirby, W. F. (1890). A Synonymic Catalogue of Neuroptera Odonata, or Dragonflies. London: Gurney and Jackson.

Kumar, A. (1973). Descriptions of the last instar larvae of Odonata from the Dehra Dun Valley (India), with notes on Biology I. (suborder Zygoptera). Oriental Insects, 7(1), 83-118.

Lieftinck M. A. (1940). Revisional notes on some species of Copera Kirby, with notes on habits and larvae (Odon., Platycneminidae). Treubia Buitenzorg, 17, 281-306.

MacNeill, N. (1960). A study of the caudal gills of dragonfly larvae of the sub-order Zygoptera. Proceedings of the Royal Irish Academy. Section B: Biological, Geological, and Chemical Science, 61, 115-140.

Matsuki, K. (1993). Description of the larva of Copera ciliata (Sélys, 1863) (Odonata, Platycnemidae) from Taiwan. Tombo, 36, 22-24.

Navás, R. P. L. (1934). Névroptères et insectes voisins - Chine et pays environnants - (Septième Série). Notes d'Entomologie Chinoise, 2(1), 1-16.

Needham, J. G. (1930). A manual of the dragonflies of China. Peiping: The Fan Memorial Institute of Biology.

Orr, A. G. (2005). Dragonflies of Peninsular Malaysia and Singapore. Borneo: Natural History Publication.

Orr, A. G., \& Dow, R. A. (2015). Description of the final stadium larvae of Onychargia atrocyana Sélys, 1865 from Sarawak, identified using DNA barcoding (Odonata: Zygoptera: Platycnemididae), with an overview of larval characters in the Platycnemididae. Zootaxa, 4040(3), 384-392. doi:10.11646/zootaxa.4040.3.9

Phan, Q. (2019, October 20). The IUCN Red List of Threatened Species: Copera chantaburii [Online]. Retrieved from: https://www.iucnredlist.org/species/190834/8834941.

Rambur, P. (1842). Histoire naturelle des insectes. Névroptères. Paris: Librairie Encyclopédique de Roret.

Rowe, R. J. (1992). Ontogeny of agonistic behavior in the territorial damselfly larvae, Xanthocnemis zeulundica (Zygoptera: Coenagrionidae). Journal of Zoology, London, 226, 81-93.

Saetung, T., \& Boonsoong, B. (2016). Description of the final instar larva of Pseudagrion pruinosum (Burmeister, 1839) (Odonata: Coenagrionidae) from Thailand. Zootaxa, 4175, 292-300. doi:10.11646/zootaxa.4175.3.8

Saetung, T., \& Boonsoong, B. (2019). A review of genus Agriocnemis larva (Odonata: Coenagrionidae) from Thailand including a description of the final stadium larva of Agriocnemis minima Selys, 1877 with supporting molecular (COI) data. Zootaxa, 4711(3), 579-599. doi:10.11646/zootaxa.4711.3.9

Sahni, D. N. (1965). Studies on the Odonata (Zygoptera) of Nainital. Indian Journal of Entomology, 27(2), $205-216$.

Schorr, M., \& Paulson, D. (2019, November 24). World Odonata List. [Online] Retrieved from: https://www.pugetsound. edu/academics/academic-resources/slater-museum/biodiversity-resources/dragonflies/world-odonata-list2/

Sélys de Longchamps, M. E. (1863). Synopsis des Agrionines. Quatrième légion: Platycnemis. Bulletin de l'Académie royale de Belgique (Série 2), 16(8), 147-176. 
Shorthouse, D. P. (2019, July 15). SimpleMappr, an online tool to produce publication-quality point maps. Citing online sources: advice on online citation formats. [Online] Retrieved from: http://www.simplemappr.net.

Watson, M. C. (1956). The utilization of mandibular armature in taxonomic studies of anisopterous nymphs. Transactions of the American Entomological Society, 81(3/4), 155-202.

Yum, J. W., \& Bae, Y. J. (2007). Description of the Larva of Copera tokyoensis Asahina (Insecta: Odonata: Platycnemididae) from Korea. Korean Society of Systematic Zoology, 23(1), 87-89.

Appendix 1. List of photographic records of Copera chantaburii.

\begin{tabular}{|c|c|c|c|}
\hline Location & Photographer's name & Sex & Date \\
\hline Chiang Mai Province, San Sai Noi & W. Panadit & $\begin{array}{c}1 q \\
1 q \\
1 \% \\
1 \text { copula } \\
1 \% \\
1 \sigma^{7}, 2 q\end{array}$ & $\begin{array}{l}18 \text { September } 2010 \\
24 \text { July } 2012 \\
28 \text { October } 2012 \\
21 \text { July } 2017 \\
\text { 27 September } 2017 \\
3 \text { January } 2018\end{array}$ \\
\hline $\begin{array}{l}\text { Nakhon Ratchasima Province, } \\
\text { Kham Thale Sor }\end{array}$ & N. Runghirun & $\begin{array}{l}1 \text { copula } \\
1 \sigma^{7}, 1 \%\end{array}$ & $\begin{array}{l}12 \text { November } 2016 \\
7 \text { November } 2017\end{array}$ \\
\hline $\begin{array}{l}\text { Petchaburi Provinces, Khao Yoi } \\
\text { Arboretum }\left(13^{\circ} 13^{\prime} 10.7^{\prime \prime} \mathrm{N}\right. \\
\left.99^{\circ} 46^{\prime} 06.12^{\prime \prime} \mathrm{E}\right) \text { altitude } 68 \mathrm{~m}\end{array}$ & $\begin{array}{l}\text { R. Ruangrong and S. Tesring } \\
\text { T. Thitiarchagul } \\
\text { S. Tesring } \\
\text { N. Thepphibalsathit }\end{array}$ & $\begin{array}{c}10 \sigma^{7}, 4 \circ \\
4 \sigma^{7} \\
5 \sigma^{7} \\
1 \sigma^{7} \\
1 \% \\
1 \sigma^{7}, 1 \% \\
2 \sigma^{7} \\
3 \sigma^{7} \\
1 \sigma^{7} \\
2 \sigma^{7} \\
1 \% \\
6 \sigma^{7} \\
3 \sigma^{7} \\
2 \sigma^{7} \\
7 \sigma^{7}, 3 q \\
1 \sigma^{7} \\
2 \sigma^{7} \\
2 \sigma^{7}, 1 \%, 1 \text { copula } \\
1 \sigma^{\pi}\end{array}$ & $\begin{array}{c}11 \text { September } 2016 \\
7 \text { October } 2016 \\
\text { 15 November } 2016 \\
16 \text { July } 2017 \\
14 \text { August } 2017 \\
2 \text { September } 2017 \\
9 \text { October } 2017 \\
26 \text { November } 2017 \\
20 \text { December } 2017 \\
30 \text { December } 2017 \\
7 \text { November } 2015 \\
26 \text { December } 2015 \\
\text { 19 July } 2016 \\
14 \text { November } 2015 \\
10 \text { December } 2015 \\
\text { 23 December } 2017 \\
\text { 10 December } 2016 \\
21 \text { January } 2017 \\
2 \text { October } 2016\end{array}$ \\
\hline $\begin{array}{l}\text { Prachin Buri Province, } \\
\text { Prachantakham } \\
\left(14^{\circ} 5^{\prime} 13^{\prime \prime} \mathrm{N}, 101^{\circ} 31^{\prime} 38^{\prime \prime} \mathrm{E}\right) \\
\text { altitude } 12 \mathrm{~m}\end{array}$ & J. Sim & $7 \sigma^{7}, 12 \circ$ & 23 August -24 November 2017 \\
\hline $\begin{array}{l}\text { Samut Prakan Province, } \\
\text { Bang Kachao }\end{array}$ & P. Dawwrueng & $10^{x}, 1$ 우 & 12 May 2014 \\
\hline Ubon Ratchathani Province, Muang & P. Thanomjit & 10 & 12 May 20144 December 2016 \\
\hline $\begin{array}{l}\text { Udon Thani Province, } \\
\text { Ban Plue }\left(17^{\circ} 40^{\prime} 56^{\prime \prime} \mathrm{N},\right. \\
\left.102^{\circ} 27^{\prime} 51^{\prime \prime} \mathrm{E}\right) \text { altitude } 9 \mathrm{~m}\end{array}$ & N. Komanasin & $10^{7}$ & 11 October 2019 \\
\hline
\end{tabular}


Appendix 2. Measurements $(\mathrm{mm})$ of Copera chantaburii $(\mathrm{n}=5)$ and Pseudocopera ciliata $(\mathrm{n}=4)$

\begin{tabular}{|c|c|c|c|c|c|c|}
\hline & \multicolumn{3}{|c|}{ Copera chantaburii } & \multicolumn{3}{|c|}{ Pseudocopera ciliata } \\
\hline & Min. & Max. & Average & Min. & Max. & Average \\
\hline Length of body without caudal lamellae & 9.31 & 12.17 & 10.72 & 11.89 & 13.94 & 12.92 \\
\hline Caudal lamellae length & 3.31 & 4.24 & 3.79 & 12.49 & 13.54 & 13.02 \\
\hline Maximum head width & 2.16 & 2.38 & 2.23 & 2.45 & 2.50 & 2.48 \\
\hline Antenna length & 1.20 & 2.01 & 1.77 & 2.23 & 2.34 & 2.29 \\
\hline Maximum prementum width & 1.43 & 1.76 & 1.58 & 1.45 & 1.64 & 1.55 \\
\hline Prementum length & 1.73 & 1.76 & 1.74 & 1.79 & 2.16 & 1.98 \\
\hline Labial palp length & 0.63 & 0.86 & 0.79 & 0.78 & 0.79 & 0.79 \\
\hline Movable hook length & 0.40 & 0.52 & 0.47 & 0.43 & 0.43 & 0.43 \\
\hline Inner wing pads length & 3.32 & 3.57 & 3.46 & 3.92 & 4.28 & 4.10 \\
\hline Outer wing pads length & 3.17 & 3.52 & 3.34 & 3.74 & 3.85 & 3.80 \\
\hline Fore femora length & 1.17 & 1.59 & 1.43 & 2.94 & 3.10 & 3.02 \\
\hline Fore tibiae length & 1.00 & 1.88 & 1.57 & 3.70 & 3.88 & 3.79 \\
\hline Fore tarsi length & 0.71 & 0.87 & 0.77 & 1.20 & 1.23 & 1.22 \\
\hline Mid femora length & 1.43 & 2.04 & 1.79 & 3.94 & 4.45 & 4.20 \\
\hline Mid tibiae length & 1.49 & 2.21 & 1.88 & 4.44 & 4.86 & 4.65 \\
\hline Mid tarsi length & 0.62 & 0.99 & 0.77 & 1.34 & 1.39 & 1.37 \\
\hline Hind femora length & 1.95 & 2.41 & 2.24 & 4.57 & 5.07 & 4.82 \\
\hline Hind tibiae length & 1.79 & 2.38 & 2.14 & 5.36 & 5.86 & 5.61 \\
\hline Hind tarsi length & 0.66 & 0.91 & 0.81 & 1.49 & 1.72 & 1.61 \\
\hline
\end{tabular}




\section{Appendix 3. Photographs of Copera chantaburii}

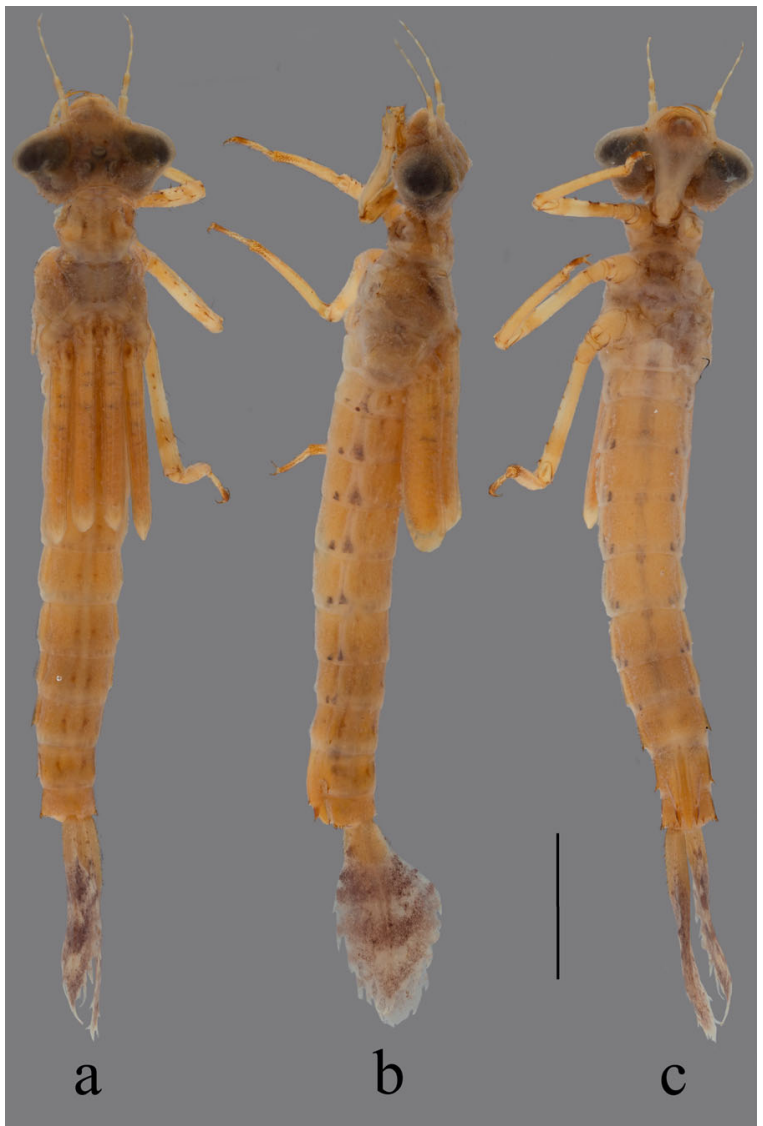

Photographs of Copera chantaburii, larval habitus: (a) dorsal view, (b) lateral view, (c) ventral view. Scale $=2 \mathrm{~mm}$. 
236 T. Saetung et al.

\section{Appendix 4. Photographs of caudal lamellae of Copera spp.}

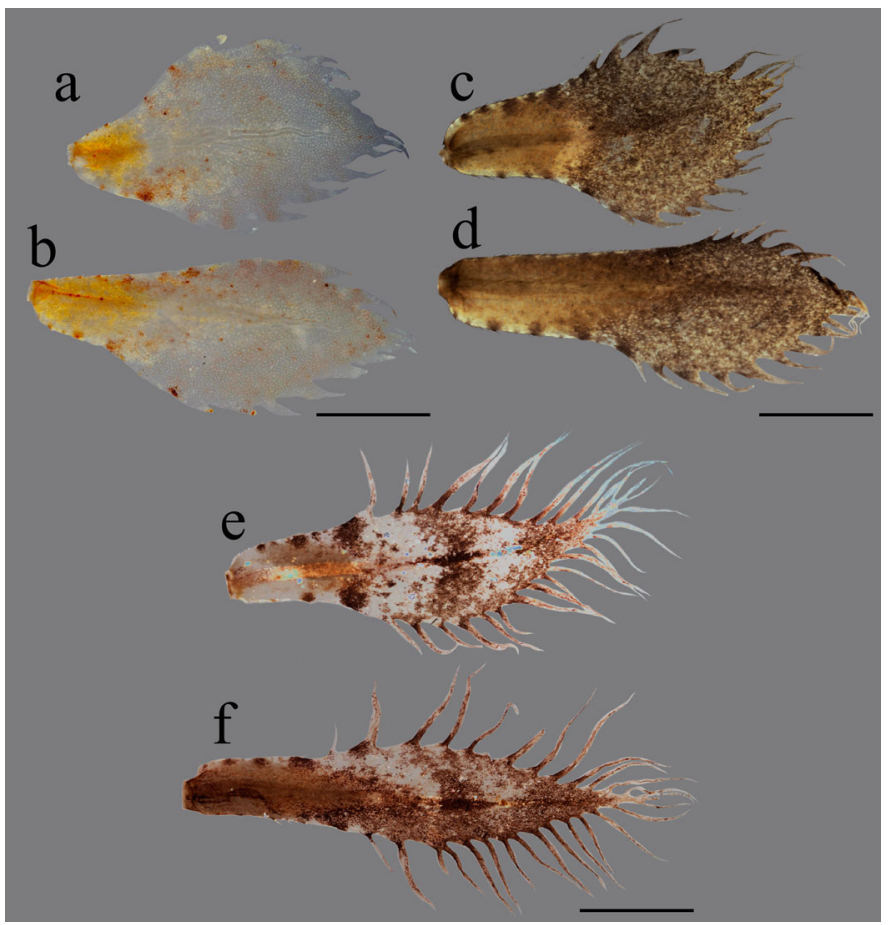

Photographs of caudal lamellae of Copera spp.: (a, b) C. chantaburii; (c, d) C. marginipes; (e, f) C. vittata; (a, c, e) median gills; (b, d, f) lateral gills. Scale $=0.5 \mathrm{~mm}$. 
Appendix 5. Habitats of Copera spp. and Pseudocopera ciliata

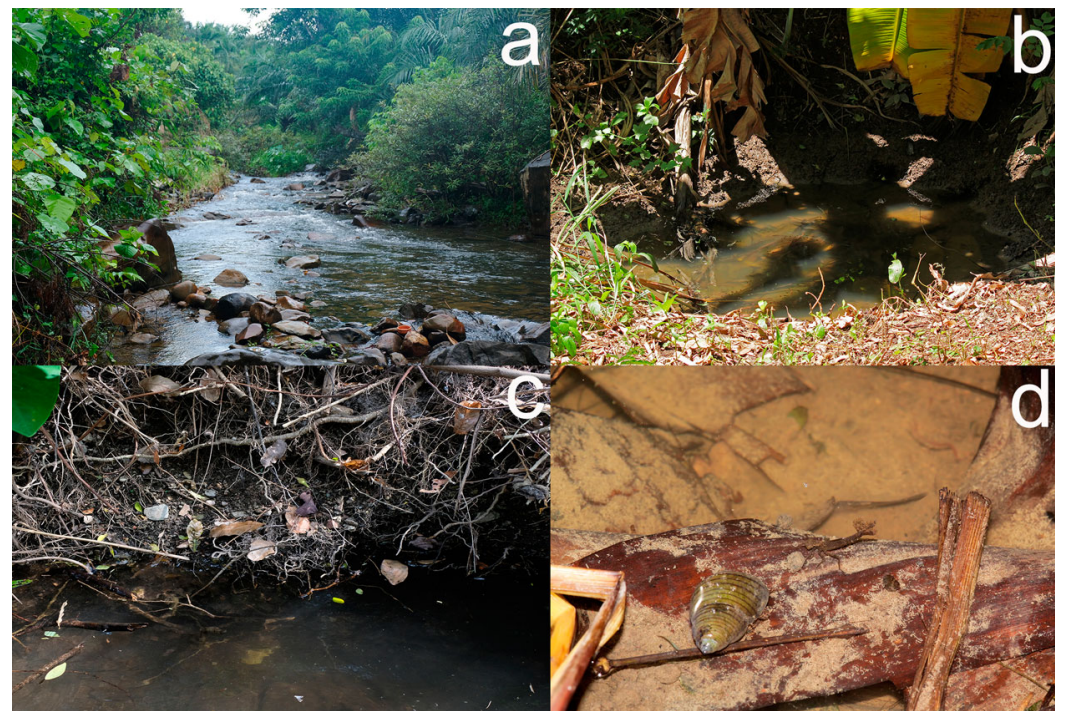

Habitats of Copera spp. and Pseudocopera ciliata: (a) stream; (b) temporary pond; (c) vegetation root; (d) leaf litter.

Appendix 6. Platycnemidinae larvae display agonistic behaviour

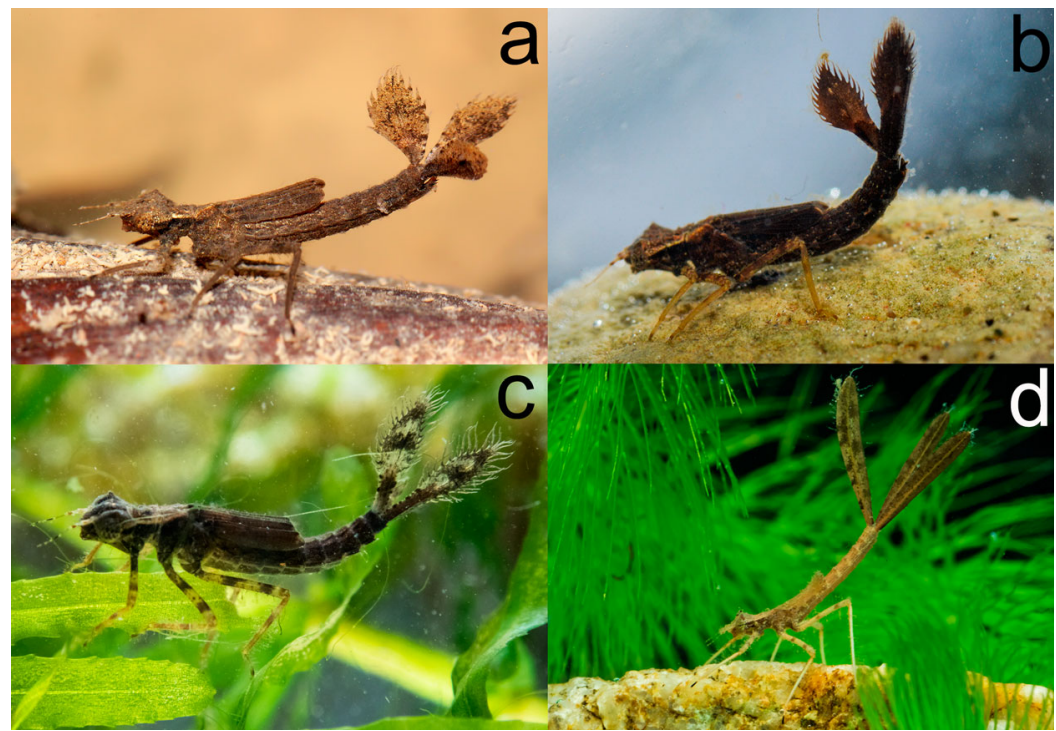

Platycnemidinae larvae display agonistic behaviour: (a) Copera chantaburii; (b) C. marginipes; (c) C. vittata; (d) Pseudocopera ciliata. 